\title{
THE EFFECT OF LOAN TO DEPOSIT RATIO AND DEBT TO EQUITY RATIO ON RETURN ON EQUITY
}

\author{
Leni Lawati \\ Universitas Langlangbuana, Indonesia \\ leniOlawati@gmail.com
}

\begin{abstract}
ROE level is the main thing for investors and potential investors. Issues of liquidity, performance efficiency, and strengthening of capital are still the main discussions. These can also affect the value of ROE. So that the research aims to determine with certainty the effect of the Loan to Deposit Ratio (LDR) and the Debt to Equity Ratio (DER) on the Return on Equity (ROE) in Islamic banking sub-sector listed on the IDX for the 2014-2018 period. The independent variables are LDR and DER while ROE is the dependent variable. The method used is quantitative. Meanwhile, the data used in this study is secondary data from the Company's Annual Financial Statements obtained from the official website of the Indonesia Stock Exchange at idx.co.id. Data testing was carried out by descriptive statistical analysis, multiple regression analysis, and hypothesis testing using SPSS. The results showed that partially LDR had a positive and significant effect on ROE and DER had no effect on ROE, while simultaneously LDR and DER had a significant effect on ROE.
\end{abstract}

Keywords: Debt to Equity Ratio; Loan to Deposit Ratio; Return On Equity

\section{INTRODUCTION}

A bank is one of the financial institutions that collect funds and then distributes them back to people who need funds, which are expected from these activities to improve people's lives. Banks also impose interest as compensation so that people want to save their funds in the bank. On the other hand, Indonesia is a country with the largest Muslim population in the world. Included in the Global Religious Future, Indonesia's population reaches $87.17 \%$ of the total population of 239.89 million people who are followers of the Islamic religion. Meanwhile, the flower system is not following Islamic Sharia law. So, the existence of Islamic banking can provide another alternative for the community because it uses a profit-sharing system. Although Indonesia has opportunities in the development of Islamic banking, the development of Islamic banks has not been optimal. In terms of assets, financing, and third-party funds, as shown in the 2018 Indonesian Sharia Financial Development Report data issued by the Financial Services Authority (OJK) from 2016 to 2018 , shows the growth that is not too positive.

One of the problems that are often faced by Islamic banking is financing, where if management is not running well, the financing will affect the level of bank liquidity, besides that the high level of debt ratio is also a problem because of the lack of incoming capital so that the funds for operations use a lot of funds originating from debt. Thus, the level of health will be disturbed. The average data on the development of Islamic banking listed on the IDX is known that the LDR level in 2014 to 2017 continued to decline even though it rose again in 2018, while the DER from 2014 to 2017 continued to rise and was above $500 \%$ even though in 2018 it fell below 500\%. Thus, the ROE level from 2014 to 2017 continued to decline and only rose again in 2018.

Research objectives: (1) To determine the positive significant effect of the Loan to Deposit Ratio (LDR) on the Return on Equity Ratio (ROE) of Islamic banking listed on the Indonesia Stock Exchange for the period 2014-2018; (2) To determine the significant negative effect of the Debt to Equity Ratio (DER) on the ROE of Islamic banking listed on the Indonesia Stock Exchange for the period 2014-2018; and (3) To determine the significant effect of LDR and DER on the ROE of sharia banks listed on the Indonesia 
Stock Exchange for the period 2014-2018. Loan to Deposit Ratio is a ratio that shows how the structure of the amount of credit given to debtors to total public savings funds and capital (Hery, 2019). Debt to Equity Ratio is a quotient that can be used as a reference in seeing the company's structure between debt to equity (Kasmir, 2015). Return On Equity is a quotient value that can see the size of the company for managing capital owned so that it can provide benefits (Hery, 2019).

\section{METHODS}

This type of research is quantitative influence research which is a quantitative study to determine whether the influence is between variables (Wiratna, 2018). This study is to determine the relationship between LDR, DER, and ROE in Islamic banking which is listed on the Indonesia Stock Exchange for the period 2014-2018. The data used is secondary data obtained from the Company's Annual Financial Statements for the period 2014 to 2018 of Islamic banks listed on the IDX and the data is taken through the official website of the IDX, namely www.idx.co.id. Retrieval and other data collection are carried out by literature study by collecting data from books, journals / scientific papers, theses, and the internet.

The population in this study were all Islamic banking companies listed on the Indonesia Stock Exchange in 2014-2018 with a total population of 10 companies. Whereas in this study the sample used was purposive sampling method based on predetermined criteria so that a sample of 8 companies was obtained with five-year annual corporate financial reports in the 2014-2018 period so that the total data was 40 financial reports. Data analysis techniques, among others, use descriptive statistical analysis methods, multiple regression analysis, and hypothesis testing.

\section{Descriptive Statistical Analysis}

\section{RESULTS AND DISCUSSION}

The research was carried out with this descriptive statistical analysis test as a testing technique that the data used as a sample can be more easily understood and applied with a statistical format. Based on testing using SPSS, the following results were obtained:

Table 1. Descriptive Statistical Analysis

\begin{tabular}{lrrrrr}
\hline & \multicolumn{5}{c}{ Descriptive Statistics } \\
& N & Minimum & Maximum & \multicolumn{1}{c}{ Mean } & Std. Deviation \\
\hline LDR & 40 & 71,87 & 99,46 & 90,1302 & 6,87484 \\
DER & 40 & 201,20 & 3047,12 & 578,0328 & 437,41119 \\
ROE & 40 & $-94,01$ & 36,50 & 5,6850 & 18,36166 \\
Valid N & 40 & & & & \\
(listwise) & & & & & \\
\hline
\end{tabular}

Source: Output SPSS (2020)

From the Descriptive Statistical Analysis table, it can be explained that:

The LDR value in the 2014-2018 period had the lowest value, namely $71.87 \%$, this was the LDR of Bank BRISyariah in 2017 and the highest was the LDR of CIMB Niaga Bank in 2014 with a value of $99.46 \%$. Based on the test results, shows that the standard deviation value of $6.87484 \%$ is much smaller than the average value of $90.1302 \%$, so the average value in the LDR sample represents the value of the entire sample data. The standard deviation value also shows that the LDR of Islamic banking fluctuates \pm $6.87484 \%$ of all sample data. The average LDR value is also in the range of $85 \%-100 \%$, this shows that the average LDR of sharia banks listed on the Indonesia Stock Exchange 
for the period 2014-2018 is included in the criteria for a fairly liquid company, as well as the maximum value of 99 . $46 \%$, which is still below $100 \%$, indicates that Islamic banking on the Indonesia Stock Exchange is still categorized as quite liquid and none of them are in the lower category. So that in general, Islamic banking that is listed on the IDX is a fairly liquid company.

The lowest value of DER on the results of descriptive statistical testing is $201.20 \%$ which is the 2018 DER for the Sharia National Pension Savings Bank, while the highest value of $3,047.12 \%$ is DER for Panin Dubai Syariah Bank 2017. The average value of DER is $578,0328 \%$ with a standard deviation of $437.41119 \%$, which means that the average value is a representative value of the overall value of the sample data. The average value which reaches $578.0328 \%$ also shows that the DER of Islamic banking in the 2014-2018 period is quite a good company that can suppress the DER value which means that operating costs are not too large from debt and a high DER value can affect performance. financial company because the company will have more expenses compared to a smaller DER ratio. Moreover, with the maximum value of DER which reaches $3,047.12 \%$, this figure is very high from the tolerance value which is usually only below $500 \%$ for banking or financial companies.

The lowest ROE value is $-94.01 \%$ which is the ROE value of Panin Dubai Syariah Bank in 2017 and the highest value is $36.50 \%$ which is the ROE value of the Sharia National Pension Savings Bank in 2017. In the test results above the average ROE, value amounted to $5.6850 \%$ with a standard deviation greater than the average value, namely $18.36166 \%$, this shows the existence of extreme data in the sample data. ROE of Islamic banking with an average value of $5.6850 \%$ means that Islamic banking is quite healthy. However, on the other hand, the lowest ROE value which touched a negative number, namely $-94.01 \%$, is very worrying, this means that the company is very unhealthy because it describes the company as not good or even unable to generate profits and can also influence investors to save their funds in the company.

\section{Multiple Regression Analysis}

The results of data testing with multiple regression analysis can be seen in Table 2 below as follows:

Table 2. Results of Multiple Regression Analysis and t-test

\begin{tabular}{lrrrrr}
\hline \multicolumn{7}{c}{ Coefficients $^{\text {Ua }}$} \\
Unstandardized & $\begin{array}{c}\text { Standardized } \\
\text { Coefficients }\end{array}$ & Coefficients & t & Sig. \\
Model & \multicolumn{1}{c}{ B } & Std. Error & \multicolumn{1}{c}{ Beta } & & \\
\hline 1 (Constant) & $-19,270$ & 15,159 & & $-1,271$ &, 212 \\
LDR &, 521 &, 167 &, 195 & 3,118 &, 004 \\
DER &,- 038 &, 003 &,- 907 & $-14,490$ &, 000
\end{tabular}

Source: SPSS output (2020)

The equation values in multiple regression are:

$Y=-19,270+0,521 X_{1}-0,038 X_{2}+e$

Based on the regression equation above, it can be explained that the results of multiple regression analysis are as follows:

The constant value of $-19,270$ is the ROE value with the assumption that the LDR and DER values are zero. Or with an explanation that if the company does not have a 
level of credit to third-party funds and also a debt ratio, the company has an ROE $(\mathrm{Y})$ of $-19,270$. The value of the LDR regression coefficient $(\beta 1)$ is 0.521 . This means that if the LDR $(X 1)$ value increases by one unit, the ROE value increases by 0.521 because it has a unidirectional relationship or a positive relationship with the assumption that the value of other variables does not change. The regression coefficient on DER ( $\beta 2)$ has a negative or opposite relationship with the value -0.038 . This means that if the DER (X2) value increases by one unit, the ROE $(Y)$ value will decrease by -0.038 and vice versa if the DER (X2) value decreases by one unit, the ROE (Y) value will increase by 0.038 assuming the variable value others have not changed.

The correlation coefficient analysis shows that the correlation coefficient $(R)$ is 0.925 , which indicates that the correlation coefficient is high. The value of 0.925 is included in the interval $0.80-1,000$ with a high level of relationship. This means that LDR and DER have a high effect on the ROE value. The relationship of the independent variable and the dependent variable on the coefficient of determination (R2) is 0.855 this value is close to the value of 1 , so it can be explained that ROE can be explained by $85.5 \%$ by the LDR and DER variables. While the remaining value, namely $14.5 \%$, is an explanation of other causes outside of the research conducted. A large $R 2$ value indicates that the data for the independent variables in this study LDR and DER have a consistent effect on the dependent variable, namely ROE, which means that the independent variables have consistent variations in influencing the independent variables.

In table 2 the results of the t-test are as follows:

The significance value (Sig.) Of LDR is 0.04 . The requirement to see that there is a significant influence is Sig. $<0.05$. Based on the significance value, $\mathrm{HO}$ is rejected and $\mathrm{Ha}$ is accepted. Meanwhile, based on the comparison between the value of the $t_{\text {count }}$ and $t_{\text {table, }}$ it is known that $t_{\text {count }}$ is 3.118 and $t_{\text {table }}$ is 2.026 . So that the calculation result of $t_{\text {count }}$ (3.118) $>t_{\text {table }}(2.026)$ and Sig. $(0.04)<0.05$, it can be concluded that $\mathrm{H} 0$ is rejected and $\mathrm{Ha}$ is accepted. The $\mathrm{t}_{\text {count }}$ value is known to be positive, which indicates that the LDR has a positive effect. This means that there is a positive and significant influence between LDR and ROE.

The significant value (Sig.) On the known DER variable is 0.00 . Meanwhile, the $t_{\text {count }}$ of $D E R$ is $-14,490$. Thus, the calculation result of $t_{\text {count }}(14,490)>t_{\text {table }}(2,026)$ indicates that there is an influence and the value of Sig. $(0.00)<0.05$, it can be concluded that $\mathrm{HO}$ is accepted and $\mathrm{Ha}$ is rejected and DER has a significant effect on ROE. The $t_{\text {count }}$ value in the DER variable shows a negative number indicating that DER has a negative effect on ROE. This means that it can be explained that DER has a negative and significant effect on ROE.

The results of the $\mathrm{F}$ test are shown in table 3 below which explains that:

Table 3 Simultaneous Test Results Test-F

\begin{tabular}{|c|c|c|c|c|c|}
\hline \multicolumn{6}{|c|}{ ANOVA $^{a}$} \\
\hline Model & Sum of Squares & Df & Mean Square & $\mathbf{F}$ & Sig. \\
\hline 1 Regression & 11244,989 & 2 & 5622,494 & 109,267 &, $000^{\mathrm{b}}$ \\
\hline Residual & 1903,889 & 37 & 51,456 & & \\
\hline Total & 13148,878 & 39 & & & \\
\hline $\begin{array}{l}\text { a. Dependent } \\
\text { b. Predictors: }\end{array}$ & $\begin{array}{l}\text { ariable: ROE } \\
\text { onstant), DER, LDR }\end{array}$ & & & & \\
\hline
\end{tabular}

Source: SPSS output (2020)

The results of the $F_{\text {table }}$ calculation above show that the significance value (Sig.) Is 0.000 , while the $F_{\text {count }}$ value is known to be 109.267 and $F_{\text {table }}$ is 3.25 . Thus, the results 
of the $F$ test show that Sig. $(0.000)<0.05$ and $F_{\text {count }}(109.267)>F_{\text {table }}(3.25)$, it can be concluded that LDR and DER simultaneously have a significant effect on ROE.

\section{Effect of LDR on ROE}

The LDR value is a description of the company's ability to meet customer withdrawals and may occur at any time from credit. LDR can also describe how much funds collected in a bank come from public funds that are channeled into credit funds. The granting of this credit will generate profits for the bank because in providing credit to fund seekers, interest or profit sharing will be given as compensation for the bank that has provided funds. Thus, the results of this interest income become the profits that the bank gets.

In Islamic banking that is listed on the IDX, the LDR value which has a positive and significant effect on ROE indicates that the higher the value of credit issued from thirdparty funds, the higher the profit earned by the bank so that the bank can also provide large dividends for investors, which indicates the value of ROE. high. As described in (Hery, 2019) that, the bank rolls back the funds it gets by providing credit so that the bank gets a profit.

The amount of credit given to Islamic banks listed on the IDX with funds originating from third-party funds encourages banks to earn profits so that they can attract investors to invest in the company. In Islamic banking listed on the Indonesia Stock Exchange, the LDR value shows that every year it has fluctuated from 2014 to 2017 is $88 \%$. In 2017 there was a decrease in the lowest LDR level, namely $87.17 \%$, this LDR value was in line with the decline in the ROE value in Islamic banking that year which touched an alarming figure of $-2.03 \%$. The decline in the LDR value can occur due to the large number of non-performing loans that can affect the company's liquidity level. Also, the level of profitability will be problematic. The problem of repaying credit has always been a major problem for banks, especially Islamic banking. Meanwhile, published in indopremier.com, there was a decrease in the level of liquidity in 2017 due to additional capital from the parent company, but the funds were not optimally disbursed in financing. Also, there are incoming hajj funds so that many funds are deposited in the bank, however, the demand for funds is not as much as the incoming funds so that there is an imbalance between incoming funds and outgoing funds to the public.

The results of the study which state that LDR has a significant effect on ROE in this study are in line with the results of research conducted by Rahmadi (2017) and the results of research conducted by (Patni \& Darma, 2017). Meanwhile, the results of this study do not support the results of research conducted by Thamrin, Wiyati, \& Oemar (2019) with the results of the research that LDR at Bank Rakyat Indonesia Tbk does not significantly affect changes in the value of ROE.

\section{Effect of DER on ROE}

DER is the yield value for total debt to total equity. The value of DER can explain whether the company can meet its obligations or debts with its assets. In Islamic banking companies listed on the Indonesia Stock Exchange for the 2014-2018 period, it is known that the average DER value reaches $500 \%$ more each year, which indicates that the debt ratio is at an unfavorable level with total liabilities five times greater than the company's assets. The high DER value resulted in the company's net profit, which is indicated by the ROE value, also having poor growth, even in 2017 it touched $-2.03 \%$ because, in that year, DER was in a quite alarming figure, namely $808.66 \%$. With a high DER, the company has more expenses to fulfill its obligations so that the profit earned is not maximized and even results in losses. 
High liability values also occur due to a lack of funds owned by the bank so that banking activities will rely on debt from other institutions which of course have loan interest so that this obligation can affect the net profit received, so the dividend distribution will automatically decrease. Also, Islamic banking activities are not supported by policies issued by the government. So far, there have been no policies that directly support the sharia economy. In the 16 economic policy packages issued by the government, there are no policies that can directly strengthen the development of Islamic banking. Thus, people are less aware of carrying out their activities in Islamic banking which causes a lack of incoming funds, and automatically the activities carried out will rely on funds from debt, which means that the value of the Islamic banking debt ratio will be of great value.

According to Sudana Andriani et al. (2015), the value of DER can affect the profit received by the company because if the DER is high, the company has the burden to meet its debts so that the company's net profit is reduced and dividends to investors will also decrease.

The theory which states that the DER value will affect the ROE level of the company is following the results of this study. Where DER affects the rise and fall of ROE.

The value of DER which has a negative effect on ROE is in line with the results of research conducted by Utami (2017) which explains that DER on ROE of BRI Syariah Bank has a significant negative effect. Meanwhile, the results of this study do not support the research conducted by Yulsiati \& Sriwijaya (2016) and the research conducted by Ridho (2012) which states that there is no influence between DER on ROE.

\section{Effect of LDR and DER on ROE}

ROE is a ratio that is measured, which is used to assess the company in obtaining profits that have been deducted by taxes from the use of company capital. Because the ROE has seen is the company's net profit to the company's capital, the value of this ratio is more considered by investors and potential investors. Investors will pay attention to ROE fluctuations every year. From the increasing ROE value, the company is considered capable of managing its capital so that it can generate maximum profit. Therefore, companies need to know what factors will affect the rise and fall of the ROE value. Based on the factors that can affect ROE, companies need to pay attention to the level of debt, the level of liquidity, and its operational activities.

This factor is evidenced by the results of this study which show that LDR and DER have a significant effect on ROE. Sharia banking that is listed on the IDX for the period 2014-2018 has not developed too optimally, there has been a sharp decline to touch negative numbers in 2017. The unstable ROE of Islamic banking is based on the not maximal level of credit in Islamic banking so that the profitability is also not optimal. Also, the level of liabilities in the 2014-2018 period is considered to be worrying for the health of the bank because it is at a very high level, such as in 2017 the debt ratio touched $808.66 \%$ where the safe limit for banking is only $500 \%$. This will put a burden on the company to fulfill its obligations so that the profit received is reduced even, the ROE value in 2017 touched the lowest figure shown in the ROE growth data for Islamic banking which experienced a loss of $-2.03 \%$.

The decline in the value of ROE is certainly a bad impact on Islamic banking, investors will withdraw their funds and potential investors will not save their funds because they are considered too risky. This is what makes Islamic banking less developed in the capital market. Problems with liquidity, capital, and performance efficiency are still frightening problems for Islamic banking in Indonesia in this study, especially those listed on the Indonesia Stock Exchange. 
The LDR and DER values that have an influence on ROE in the results of this study are in line with the results of research conducted by Akbar'Ali (2015) that LDR and DER significantly affect ROE in banking companies in Indonesia. However, this study does not support the research conducted by Utami (2017) with the results of the study showing that LDR and DER have no significant effect on ROE at PT Bank Rakyat Indonesia Syariah.

\section{CONCLUSION}

The study was conducted to determine the effect contained in the variable loan to deposit ratio (LDR) and debt to equity ratio (DER) on return on equity (ROE) in the Islamic banking sub-sector listed on the Indonesia Stock Exchange (IDX) for the 2014-2018 period. After testing, the results obtained include the LDR has a positive effect on ROE, DER has a negative effect on the ROE level whereas, LDR and DER have an effect on ROE in Islamic banking listed on the IDX for the period 2014-2018 simultaneously.

\section{REFERENCES}

Akbar'Ali, S. (2015). Analisis Pengaruh Loan To Deposit Ratio (Ldr) Dan Debt To Equity Ratio (Der) Terhadap Kinerja Keuangan Return On Equity (Roe) Perusahaan Perbankan Di Ndonesia Tahun 2009-2013. Universitas Muhamadiyah Surakarta.

Andriani Pongrangga, R., Dzulkirom, M., \& Saifi, M. (2015). Pengaruh Current Ratio, Total Asset Turnover Dan Debt To Equity Ratio Terhadap Return N Equity. Jurnaal Administrasi Bisnis.

Hery. (2019). Manajemen Perbankan. Jakarta: Pt Grasindo.

Kasmir. (2015). Pengantar Manajemen Keuangan. Jakarta: Prenamedia Group.

Patni, S. S., \& Darma, G. S. (2017). Non Performing Loan, Loan To Deposit Ratio, Net Interest Margin, Bopo, Capital Adequacy Ratio, Return On Asset And Return On Equity. Jurnal Manajemen Dan Bisnis.

Rahmadi, N. (2017). Analisis Pengaruh Capital Adequacy Ratio (Car) Dan Financing To Deposit Ratio (Fdr) Terhadap Return On Asset (Roa) Dan Return On Equity (Roe) Pada Perusahaan Bank Umum Syariah Di Indonesia. Human Falah: Jurnal Ekonomi Dan Bisnis Islam, 1(1).

Ridho, M. (2012). Pengaruh Rasio-Rasio Keuangan Dan Struktur Kepemilikan Terhadap Corporate Performance (Penelitian Empiris Pada Perusahaan Non Keuangan Lq 45 Di Bei). Jurnal Dinamika Ekonomi \& Bisnis, 9(2).

Thamrin, M., Wiyati, R., \& Oemar, F. (2019). Analsis Pengaruh Quick Ratio Dan Loan To Deposit Ratio Terhadap Return On Equity Pada Bank Rakyat Indonesia Tbk. Journal Of Chemical Information And Modeling.

Utami, M. I. A. D. (2017). Pengaruh Financing to Deposit Ratio (Fdr), dan Debt to Equity Ratio (Der) terhadap Return on Equity Ratio (Roe) Pada Pt. Bri Syariah. Uin Raden Fatah Palembang.

Wiratna, S. V. (2018). Metodologi Penelitian Bisnis dan Ekonomi Pendekatan Kuantitatif. PUSTAKABARUPRESS, Yogyakarta.

Yulsiati, H., \& Sriwijaya, J. A. P. N. (2016). Pengaruh Debt To Assets Ratio, Debt To Equity Ratio dan Net Profit Margin Terhadap Return On Equity Pada Perusahaan Property dan Real Estate yang Terdaftar Di Bursa Efek Indonesia. Jurnal Akuntanika, Politeknik Negeri Sriwijaya. 